\title{
Food preferences of Gerbillurus paeba exilis in a coastal dunefield, South Africa
}

\author{
Carol A. ASCARAY, A. McLACHLAN and R. M. RANDALL
}

\begin{abstract}
Ascaray C. M., McLachlan A. and Randall R. M. 1990. Food preferences of Gerbillurus paeba exilis in a coastal dunefield, South Africa. Acta theriol. 35: 181-189.

We investigated the potential diet of Gerbillurus paeba exilis (Shortridge and Carter, 1938) from dune slacks in the eastern Cape using food preference tests on captive animals in summer and winter. Food categories investigated were: seeds, leaves and stems, and arthropods. The seeds of Arctotheca populifolia were the most preferred food. A seasonal change in diet was found: gerbils consumed mainly arthropods and seeds in summer, while in winter, few arthropods were eaten, the preferred diet consisting chiefly of seeds. Little green plant material was ingested. The seasonal change in food preferences may influence the timing of breeding.
\end{abstract}

Department of Zoology, University of Port Elizabeth, P. O. Box 1600, Port Elizabeth 6000, South Africa

Key words: food preferences, Gerbillurus paeba exilis, costal dunefield, South Africa

\section{Introduction}

Information on the diet of rodents can be obtained by means of food preference tests. These so-called "cafeteria tests" involve offering test animals a choice of several kinds of foods and estimating the degree of their consumption (Dróżdż 1975). Dróżdż (1966) has found preference test results to be consistent with those of stomach content analyses for the vole Clethrionomys glareolus and the mouse Apodemus flavicollis. Preference tests are usually carried out in different seasons, as the diet of rodents changes according to the food available at different times of the year (Zemanek 1972, Brooks 1974, Perrin 1979, 1980a). Seasonal changes in food quality are thought to influence the timing of breeding, reproductive tactics and ultimately, the population dynamics of several rodent species (Taylor and Green 1976, Curtis and Perrin 1979, Perrin 1980b).

The hairy-footed gerbil Gerbillurus paeba is a small cricetid rodent commonly found in desert and semi-desert areas in southern Africa (Davis 1975). The species is omnivorous (Laycock 1975, Holm and Scholtz 1980), but prefers insects (Boyer 1987, Kerley 1989). Although some information is available on G. paeba populations in the Namib desert (e.g. Christian 1977, 1979, 1980a, 1980b, Boyer 1987), the Kalahari (e.g. Nel 1975, 1978, 1983, Nel and Rautenbach 1975, Nel et al. 1984, Kerley et al. 1990) and the Karoo (Kerley 1989), little is known of the most southern populations of this species. An investigation of the food preferences of a G. paeba exilis (Shortridge and Carter 1938) population in the dune slacks of the Alexandria dunefield lining the 
shores of Algoa Bay in the eastern Cape was undertaken as part of a larger study of the ecology of this species in the dunefield (Ascaray 1986). The foods eaten by G.p.exilis in the dune slacks of the Alexandria dunefield, as determined by food preference tests in summer and winter, are presented here.

\section{Methods}

Food preference tests were conducted in December, 1981 and July, 1982. Test animals were trapped in dune slacks near the Sundays River Mouth ( $33^{\circ} 44^{\prime \prime}$ S; $25^{\circ} 51^{\prime \prime}$ E). Gerbils were individually housed in plastic cages $(30 \times 20 \times 25 \mathrm{~cm})$ in tents in the field. Light and temperature regimes approximated natural conditions. Nesting material was provided in the form of tissue paper, to prevent the use of food items as nesting material. Water and laboratory pellets were freely available, so that the gerbils would not eat unpalatable foods due to excessive hunger (Curtis and Perrin 1979). Ten gerbils were used in each choice test to allow for individual variation in food preferences, as suggested by Drożdż (1975). All foods used in the test were collected in the dune slacks, usually on the day of the test.

Three choice tests were conducted each season: a seed, leaf and stem and an arthropod choice test. During each test, several foods from the same category, e.g. seeds, were presented to each gerbil and the percentage of each species eaten was estimated after $12 \mathrm{~h}$ and $36 \mathrm{~h}$. Although Drożdż $(1966,1975)$ recommended the use of a four point scale, where $0=0 \%$ eaten, $1=0-30 \%$ eaten and so on, it was felt that more accurate estimates could be obtained in the present study and the percentage of food eaten was visually estimated by volume (roughly equivalent to mass) to the nearest $10 \%$. After the completion of the three tests, the most preferred plant food and most preferred arthropod food were compared in a fourth choice test, of 12 $\mathrm{h}$ duration. In all tests, the food was placed in the cages in the early evening, just before the gerbils became active. Cage contents were thoroughly examined the next morning (after $12 \mathrm{~h}$ ) and again the following morning $(36 \mathrm{~h})$, after which the experiment was terminated. At each check nesting material was searched for possible food hoards. The next preference test usually began after a $12 \mathrm{~h}$ hiatus. In all cases, the cages were checked five minutes after the food was given to the gerbils, and the food eaten first by each gerbil was recorded.

Trial tests were conducted prior to the preference tests, to determine the amount of food to be given to the gerbils, without causing weight loss. Enough food had to be placed in the cages so that only preferred foods would be eaten and so that enough of each food would remain after the test to determine which foods were most preferred. However, the scarcity of some plants and/or seeds limited the use of these species in the preference tests. Foods were thus presented to the gerbils in approximately the proportions in which they occurred in the dune slacks. It was found that $67 \mathrm{~g}$ of seed heads (all species totalled) per gerbil was enough to ensure that some food would be left at the end of the seed tests; approximately $38 \mathrm{~g}$ of green plant material per gerbil was used in the leaf and stem preference test. Preliminary tests were not conducted on arthropods since these were trapped with difficulty in the slacks. Numbers of each species presented to the gerbils were proportional to the numbers trapped, so that many more individuals of some species than others were presented. Fortunately, those species of which only a few individuals were given to the gerbils were never all eaten, so that a false impression of their palatability was avoided.

Seed preference tests: Seeds from most plants fruiting in the dune slacks at the time were presented to the gerbils. In summer, six species were producing seed; in the winter, five. Whole seed heads were presented to the gerbils, as burrow contents showed that this was the form in which seeds were hoarded. Each gerbil received the same number of seed heads of each species. After $12 \mathrm{~h}$ and $36 \mathrm{~h}$ the seed heads were removed from the cages and examined to determine how much of each had been eaten. The percentage of each seed species eaten by each gerbil was calculated, and the mean percentage eaten by the 10 gerbils obtained for each species.

Leaf and stem preference tests: Leaves and stems of nine plant species were presented to each gerbil in summer and winter, in roughly equal proportions to their abundance in the slacks. All leaf and stem material 
was picked just before use. The percentage of each species eaten was estimated after $12 \mathrm{~h}$ and $36 \mathrm{~h}$ and the mean percentage eaten by the 10 gerbils calculated.

Arthropod preference tests: Arthropods were captured in pit traps in the dune slacks and were also caught with hand-held nets. All arthropods were presented live to the gerbils and plastic mesh was placed over each cage to prevent their escape. In summer, 12 species of arthropod were trapped and presented to the gerbils. The mean percentage of each species eaten by the 10 gerbils was estimated. Only three arthropod species were trapped in winter, and because so little food was given to the gerbils, the experiment was terminated after $12 \mathrm{~h}$.

Preferred plant versus preferred arthropod test: Having established the preferred plant and arthropod foods in summer and winter, the gerbils were presented with roughly equal amounts (by mass) of the two types of food, in an attempt to discover in what proportions plant and animal foods were eaten. The percentage of each food type eaten was estimated after $12 \mathrm{~h}$.

\section{Results}

Food preferences were usually clear after $12 \mathrm{~h}$ and results were similar for the two seasons (Table 1). Arctotheca populifolia was the preferred food, with more than $90 \%$ of the test food being eaten after $36 \mathrm{~h}$ in both seasons. Gazania rigens and Senecio inaequidens seeds were also favoured in both seasons, although less $S$. inaequidens was eaten in winter than in summer. Scirpus nodosus seeds were the least preferred food in summer and winter. The strong preference for $A$. populifolia seeds was confirmed by the fact that all the test animals were observed to eat this species first when they began feeding.

Some difficulty was experienced in ascertaining whether the seeds of Helichrysum praecinctum, Juncus kraussi and $S$. nodosus, which are all small $(1-0,5 \mathrm{~mm}$ in diameter), were actually eaten by the gerbils. Seed heads were counted as being eaten if they were torn open or chewed. It is known that rodents generally prefer big seeds (Lemen 1978, Price 1983). When given seed particles of similar nutritive value, rodents select the largest seeds first (Abramsky 1983). Unless these small seeds provide some nutrient lacking in the larger seeds, the chances of gerbils actually selecting such seeds seem small. In any case, preference tests indicated that they were not favoured by the gerbils.

Sporobolus virginicus, the most common grass in the slacks, was not seeding at the time of the summer preference test. It would be interesting to know whether these seeds

Table 1. Seed preference of G. p. exilis from the dune slacks in summer and winter expressed as mean \% eaten after $36 \mathrm{~h}$. (Mean \% eaten after $12 \mathrm{~h}$ is shown in parentheses.).

\begin{tabular}{lcccc}
\hline Plant species & Summer & Range & Winter & Range \\
\hline Arctotheca populifolia & $91(78)$ & $80-100$ & $92(68)$ & $70-100$ \\
Gazania rigens & $66(37)$ & $30-100$ & $65(50)$ & $50-90$ \\
Senecio inaequidens & $63(9)$ & $10-100$ & $43(31)$ & $0-70$ \\
Helichrysum praecinctum & $27(3)$ & $0-60$ & $36(30)$ & $0-70$ \\
Juncus kraussii & $8(4)$ & $0-10$ & - & - \\
Scirpus nodosus & $1(1)$ & $0-10$ & $11(10)$ & $0-40$ \\
\hline
\end{tabular}


Table 2. Leaf and stem preference of $G$. p. exilis from the dune slacks in summer and winter expressed as mean \% eaten after $36 \mathrm{~h}$. (Mean \% eaten after $12 \mathrm{~h}$ is shown in parentheses.).

\begin{tabular}{lcccc}
\hline Plant species & Summer & Range & Winter & Range \\
\hline Arctotheca populifolia & $12(9)$ & $0-50$ & $37(18)$ & $10-50$ \\
Gazania rigens & $1(1)$ & $0-10$ & $2(1)$ & $0-20$ \\
Senecio inaequidens & $1(1)$ & $0-10$ & $1(1)$ & $0-10$ \\
Helichrysum praecinctum & $2(2)$ & $0-10$ & $2(0)$ & $0-10$ \\
Juncus kraussii & $1(1)$ & $0-10$ & $10(10)$ & $0-60$ \\
Scirpus nodosus & $0(0)$ & - & $0(0)$ & - \\
Sporobolus virginicus & $6(6)$ & $0-10$ & $38(34)$ & $0-60$ \\
Mariscus congestus & $3(3)$ & $0-10$ & $11(9)$ & $0-40$ \\
Psoralea repens & $0(0)$ & - & $4(3)$ & $0-10$ \\
\hline
\end{tabular}

Table 3. Arthropod preference of $G$. p. exilis from the dune slacks in summer expressed as mean \% eaten after $36 \mathrm{~h}$. (Mean \% eaten after $12 \mathrm{~h}$ is shown in parentheses. $\mathrm{n}=$ no. of individual insects available per gerbil.).

\begin{tabular}{lrcc}
\hline Species & $\mathrm{n}$ & $\begin{array}{c}\text { Mean } \% \text { eaten } \\
\text { after } 36 \mathrm{~h}\end{array}$ & Range \\
\hline Acanthacris ruticornis (grasshopper) & 2 & $100(100)$ & - \\
Antestiopsis orbitalis (stink bug) & 3 & $98(80)$ & $80-100$ \\
Pternoscirtus sp. (grasshopper) & 8 & $96(96)$ & $70-100$ \\
Dichranocnemus pulcher (beetle) & 7 & $96(93)$ & $50-100$ \\
Talorchestia capensis (amphipod) & 5 & $93(63)$ & $50-100$ \\
Platypleura hirtipennis (cicada) & 2 & $90(90)$ & $0-100$ \\
Labidura riparia (earwig) & 3 & $82(60)$ & $30-100$ \\
Cicindela candida (tiger beetle) & 10 & $81(76)$ & $30-100$ \\
Zophosis sp. (beetle) & 5 & $65(50)$ & $0-100$ \\
Tylos capensis (isopod) & 3 & $58(33)$ & $0-100$ \\
Gonocephalum apterum (beetle) & 2 & $10(10)$ & $0-100$ \\
Etrichodia crux (assassin bug) & 1 & $10(0)$ & $0-50$ \\
\hline
\end{tabular}

Table 4. Arthropod preference of G. p. exilis from the dune slacks in winter expressed as mean $\%$ eaten after $12 \mathrm{~h}$. $(\mathrm{n}=\mathrm{no}$. of individual insects available per gerbil.).

\begin{tabular}{lrcc}
\hline Species & n & $\begin{array}{c}\text { Mean \% eaten } \\
\text { after } 36 \mathrm{~h}\end{array}$ & Range \\
\hline Labidura riparia (earwig) & 7 & 59 & $20-90$ \\
Talorchestia capensis (amphipod) & 10 & 70 & $20-90$ \\
Tylos capensis (isopod) & 5 & 0 & - \\
\hline
\end{tabular}

are a favoured gerbil food. However, as seeds are produced for a relatively short period during the summer, this species would serve as a short-lived food resource. A great liking for the seeds of another grass, Erharta villosa, was found in captive gerbils prior to the preference tests. These seeds are, however, unlikely to form a major part of the diet of G. p. exilis, since E. villosa is scarce in the slacks. Not enough seeds could be collected to include this species in the preference tests. 
Table 5. Preferred plant food versus preferred arthropod food in summer and winter. Results expressed as \% food eaten after $12 \mathrm{~h}$. na= not available.

\begin{tabular}{lcclccc}
\hline \multirow{2}{*}{ Species } & \multicolumn{2}{c}{ Summer } & & \multicolumn{2}{c}{ Winter } \\
\cline { 2 - 3 } \cline { 7 - 8 } & $\begin{array}{c}\% \text { eaten } \\
\text { after } 12 \mathrm{~h}\end{array}$ & Range & & $\begin{array}{c}\% \text { eaten } \\
\text { after } 12 \mathrm{~h}\end{array}$ & Range \\
\hline Arctotheca populifolia & 97 & $90-100$ & & 84 & $50-100$ \\
Pternoscirtus sp. & 99 & $90-100$ & & na & na \\
Talorchestia capensis & na & na & & 31 & $10-50$ \\
\hline
\end{tabular}

Table 2 shows the summer and winter preferences of G. p. exilis for leaves and stems. It was clear from the small amount of food eaten that green plant material is not eaten in significant quantities in the dune slacks. The largest percentage of food volume presented of any species eaten in summer was $13 \%$ (A. populifolia), while less than $10 \%$ of all the other species was eaten. More green plant material was consumed during the winter months. A. populifolia and $S$. virginicus were the most favoured foods, $37 \%$ and $38 \%$ of volume presented of these species being eaten respectively. The stems, rather than the leaves, of these two species were eaten. The consumption of some other species such as $J$. kraussi and Mariscus congestus also increased in winter. The foods eaten first by the gerbils in the winter test indicated that green plant material is not a favoured gerbil food, even in winter: after five minutes, three gerbils were not eating at all, three gerbils were eating laboratory pellets, which, according to Drożdż (1966), are only eaten when other food is unacceptable; two ate $A$. populifolia, one ate $S$. virginicus and one ate $M$. congestus.

It is evident from Table 3 that arthropods are a highly preferred gerbil food in summer. Several insect species, including two grasshopper species, and amphipods all appeared to be equally favoured. However, since equal numbers of these species were not used, some species may have appeared to be more favoured than they are in the wild. Only two species appeared to be unpalatable: an assassin bug Etrichodia crux and a beetle Gonocephalum apterum. It is not known whether these contained toxins or unpleasant tasting substances. Wings and legs of the larger insects were usually not eaten. Four gerbils ate white grasshoppers Pternoscirtus sp., first; four ate cicadas Platypleura hirtipennis, first, and two ate tiger beetles Cicindela candida, first. All these insects were highly favoured foods, as indicated by the preference test. The gerbils consumed large quantities of arthropods - one gerbil, for example, ate 31 insects, two of which were large Acanthacris ruticornis grasshoppers, in one night.

In winter, only three arthropod species were presented to the gerbils (Table 4). Of these, amphipods, Talorchestia capensis, were the most preferred food (they were also highly favoured in summer). No isopods Tylos capensis, were eaten, although some had been consumed in summer. Most of the Tylos capensis placed in the cages had their heads bitten off, but these were not eaten. Five minutes after the start of the test, the gerbils were eating either laboratory pellets or nothing, which may indicate that little arthropod food is consumed during the winter months. 
When gerbils were presented with a choice of $A$. populifolia seed heads, the most preferred summer plant food, and white grasshoppers, the most abundant of the highly preferred arthropod foods, both were eaten with equal relish (Table 5). Although grasshoppers appear to be slightly more preferred than seed heads, all gerbils were seen to be eating seed heads when cages were checked after five minutes. In winter, the gerbils were given a choice of $A$. populifolia seed heads and amphipods Talorchestia capensis. After $12 \mathrm{~h}, 84 \%$ of the plant material had been eaten, while only $31 \%$ of the amphipods were eaten. Seven gerbils ate seed heads first, while three ate amphipods first.

\section{Discussion}

Gerbillurus paeba exilis in the Alexandria dunefield slacks appears to feed largely on the seeds of dune plants, those of $A$. populifolia being the most preferred. This preference for $A$. populifolia may be due to a high energy content of the seeds, since energy plays an important role in rodent dietary choices (Reichman 1977, Kerley 1991). Food stores and food remains in several burrows were similarly found to consist chiefly of this species. This preference for A. populifolia may affect its abundance in the dune slacks. Hayward and Phillipson (1979) have documented several cases where rodent foraging has reduced the relative abundance of favoured food species in different habitats. Both the seeds of $A$. populifolia and $G$. rigens, the next most preferred seed types, are available in the slacks all year. The gerbils feed chiefly from seed heads, which form a stationary and easily located food resource. They store seeds in this form in their burrows. Very little green plant material is eaten, possibly as a result of salt-spray deposition on the vegetation. Also, the availability of moisture through rainfall and a high water table ( $<70 \mathrm{~cm}$ below sand surface) is such that gerbils do not
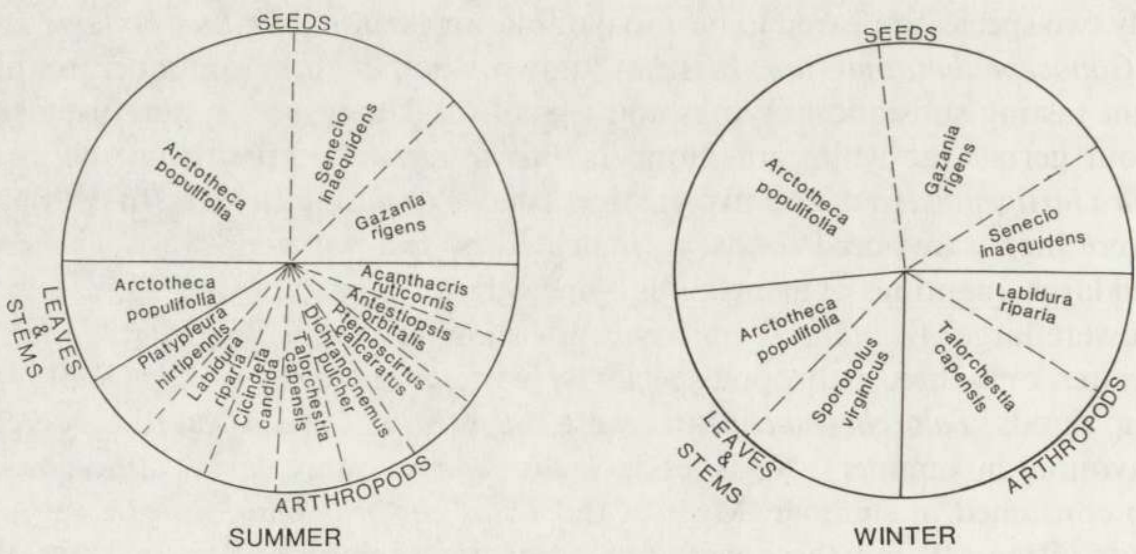

Fig. 1. The food preferences, expressed as percentage food volumes, of G. p. exilis in the dune slacks in summer and winter. 
need green plant material for its moisture content. In summer, the gerbils exploit the large numbers of arthropods present in the slacks.

The food preferences of G. p. exilis in the dune slacks are summarised in Fig. 1. The exact proportions of the three food categories consumed in nature are unknown; the figure shows approximate proportions of seeds, leaves and stems and arthropods eaten in summer and winter based on the experiments and availability. G. p. exilis shows a marked seasonal change in food preferences. In summer, little green plant material is ingested, while seeds and arthropods are taken in approximately equal proportions. In winter, because few arthropods are present in the slacks, the preferred food consists chiefly of seeds, with more green plant material being eaten than in summer. These results are consistent with those of Nel et al. (1984), who state that the diet of G. paeba in the Kalahari Gemsbok National Park, deduced from stomach analyses, comprised $70-80 \%$ seeds, $20-44 \%$ green plant material and, in summer, up to $20 \%$ insects. Similarly in the Karoo $G$. paeba consumed insects in relation to their abundance (Kerley 1989) and in the Namib this species was primarily insectivorous (Boyer 1987). Although the preference tests indicated that captive G. p. exilis individuals eat a high proportion of insects, the numbers of insects actually eaten in their natural environment may be much smaller, since the gerbils would encounter fewer insects and have more difficulty catching them, than in the test cages.

G. p. exilis's omnivorous habits allow it to utilize several different food resources in the dune slacks. The seasonal breeding pattern of this species in the Alexandria dunefield (Ascaray 1986) may be caused by the seasonal change in diet, from mainly green plant material and seeds in winter to a more nutritious diet containing insects in summer. Seasonal breeding in Rhabdomys pumilio has similarly been partly ascribed to the ingestion of insects in summer (Perrin 1980b), while Taylor and Green (1976) have shown that food quality is important in the seasonal reproduction of three African rodent species. By producing young in spring and summer $G$. p. exilis can utilize an abundant, nutritious food supply.

Because the present tests took place in conjunction with a long term mark-recapture study, no stomach contents could be obtained from gerbils in the study area. The results of the preference tests thus indicate only the potential foods of gerbils in the dune slacks, and not the actual foods eaten under natural conditions. However, Drożdż (1966) has found preference test results to be consistent with those of stomach content analyses in moles andmice.

Acknowledgements: We thank P. Du Toit for field assistance. A.C.S.I.R. bursary to the first author is gratefully acknowledged, as is funding from the Department of Environmental Affairs and the Director of Forestry.

\section{References}

Abramsky Z. 1983. Experiments on seed predation by rodents and ants in the Israeli desert. Oecologia 57: $328-332$.

Ascaray C. M. 1986. An ecological study of the hairy-footed gerbil, Gerbillurus paeba in an eastern Cape dunefield. M. Sc. Thesis, Univ. Port Elizabeth, Port Elizabeth, R. S. A. 
Boyer D. C. 1987. Effects of rodents on plant recruitment and production in the dune area of the Namib Desert. M. Sc. Thesis, Univ. Natal, Pietermaritzburg, R. S. A.

Brooks P. M. 1974. The ecology of the four-striped field mouse, Rhabdomys pumilio (Sparrman, 1784), with particular reference to a population on the Van Riebeeck Nature Reserve, Pretoria. Ph. D. Thesis, Univ. Pretoria, Pretoria, R. S. A.

Christian D. P. 1977. Effects of fire on small mammal populations in a desert grassland. J. Mammal. 58: $423-427$.

Christian D. P. 1979. Comparative demography of three Namib desert rodents: responses to the provision of supplementary water. J. Mammal. 60: 679-690.

Christian D. P. 1980a. Vegetative cover, water resources and micro-distributional patterns in a desert rodent community. J. Anim. Ecol. 49: 807-816.

Christian D. P. 1980b. Patterns of recovery from low numbers in Namib desert rodents. Acta theriol. 25 : $431-450$.

Curtis B. A. and Perrin M. R. 1979. Food preference of the vlei rat (Otomys irroratus) and the four striped mice (Rhabdomys pumilio). S. Afr. J. Zool. 14: 224-229.

Davis D. H. S. 1975. Genera Tatera and Gerbillurus. [In: The mammals of Africa: an identification manual. J. A. J. Meester and H. W. Setzer, eds]. Smithsonian Institute Press, Washington D. C., Parts 6, 4: 1 - 7.

Drożdż A. 1966. Food habits and food supply of rodents in the beech forest. Acta theriol. 11: 363-384.

Drożdż.A. 1975. Feeding and Nutrition. [In: Method for ecological bio-energetics. W. Grodziński, R. Z. Klekowski and A. Duncan, eds]. Blackwell Scientific Publications, Oxford. IBP Handbook 24: $325-351$.

Hayward G. F. and Phillipson J. 1979. Community structure and functional role in ecosystems. [In: Ecology of small mammals. D. M. Stoddart, ed.]. Chapman \& Hall, London: 135-211.

Holm E. and Scholtz C. H. 1980. Structure and patterns of the Namib desert dune ecosystem at Gobabeb. Madoqua 12: 5-39.

Kerley G. I. H. 1989. Diet of small mammals from the Karoo, South Africa. S. Afr. J. Wildl. Res. 19: 67-72.

Kerley G. I. H. 1991. What do mice select for in seeds? Oecologia. [in print]

Kerley G. I. H., Knight M. H. and Erasmus T. 1990. Small mammal microhabitat use and diet in the southern Kalahari, South Africa. S. Afr. J. Wildl. Res. 20. [in print]

Laycock P. A. 1975. A brief gerbil trapping survey in an inter-dune valley in the Namib desert. Madoqua 4: 95-97.

Lemen C. A. 1978. Seed size selection in heteromyids: a second look. Oecologia 35: 13-19.

Nel J. A. J. 1975. Aspects of the social ethology of some Kalahari rodents. Z. Tierpsychol. 37: 322-331.

Nel J. A. J. 1978. Habitat heterogeneity and changes in small mammal community structure and resource utilization in the southern Kalahari. Bull. Carnegie Mus. Nat. Hist. 6: 118-131.

Nel J. A. J. 1983. Changes in population structure of Kalahari rodents over a decade: $1970-1980$. Ann. Mus. Roy. Afr. Centr. Sc. Zool. 237: 173-178.

Nel J. A. J. and Rautenbach I. L. 1975. Habitat use and community structure of rodents in the southern Kalahari. Mammalia 39: 9-29.

Nel J. A. J., Rautenbach I. L., Els D. A. and De Graaff G. 1984. The rodents and other small mammals of the Kalahari Gemsbok National Park. Proc. Symposium: The Kalahari Ecosystem. Koedoe supplement.

Perrin M. R. 1979. Seasonal variation in the growth, body composition and diet of Clethrionomys gapperi in spruce forest. Acta theriol. 24: 299-318.

Perrin M. R. 1980a. The feeding habits of two co-existing rodents, Rhabdomys pumilio (Sparrman, 1784) and Otomys irroratus (Brants, 1827) in relation to rainfall and reproduction. Acta Oecologica/Oecol. Gener. 1: $71-89$. 
Perrin M. R. 1980b. The breeding strategies of two co-existing rodents, Rhabdomys pumilio and Otomys irroratus: with a brief review of some pertinent life history ideas. Acta Oecologica/Oecol.Gener. 1: $383-410$.

Price M. V. 1983. Laboratory studies of seed size and seed species selection by heteromyid rodents. Oecologia (Berlin) 60: 259-263.

Reichman O. J. 1977. Optimization of diets through food preferences by heteromyid rodents. Ecology 58 : $454-457$.

Taylor K. D. and Green M. G. 1976. The influence of rainfall on diet and reproduction in four African rodent species. J. Zool., Lond. 180: 367-389.

Zemanek M. 1972. Food and feeding habits of rodents in a deciduous forest. Acta theriol. 17: 315-325.

Received 15 June 1990, accepted 11 February 1991. 